\title{
サツマイモ焼酎廃液に含まれる植物生長阻害物質 カフェ酸エチルの単離と同定
}

\author{
奥野成倫 ${ }^{8}$, 田原秀隆*, 浮田和貴*，森山和之*， \\ 平井伸博**, 吉元 誠 \\ 九州沖縄農業研究センター \\ *霧島酒造(株) \\ **京都大学国際融合創造センター
}

\author{
Isolation and Identification of Ethyl Caffeate, a Plant Growth Inhibitor, \\ from a Sweetpotato Shochu Distillery By-product

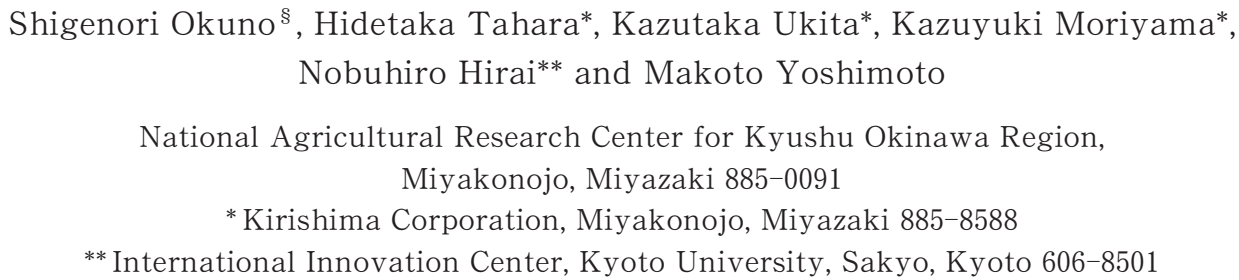

Sweetpotato shochu is a spirit that is mainly produced in the southern Kyushu area in Japan. During the course of our search for biologically active compounds in sweetpotato shochu distillery by-products, we reported that the extracts of a by-product inhibited lettuce seed germination. In the present study, in order to clarify the active compounds, the by-product was subjected to bioassay-guided fractionation using lettuce. A caffeic acid derivative was isolated from the by-product by bioassay-guided fractionation using high-performance liquid chromatography (HPLC). The derivative was identified as ethyl caffeate by ${ }^{1} \mathrm{H}$ nuclear magnetic resonance (NMR) and electron impact mass spectrometry (EIMS). The inhibitory activity of ethyl caffeate on the growth of selected plants was examined in the laboratory. At a concentration of more than $0.62 \mathrm{mM}$, ethyl caffeate significantly inhibited lettuce radicle elongation. However, seed germination was not affected. It was observed that the inhibitory activity of ethyl caffeate on lettuce radicle elongation was greater than that of caffeic acid. In the case of weeds, ethyl caffeate inhibited the seed germination of smooth pigweed by $29 \%$ and $48 \%$ at concentrations of 0.62 and $1 \mathrm{mM}$, respectively ; however, southern crabgrass was not affected. In addition, ethyl caffeate inhibited radicle elongation of smooth pigweed by $79 \%$ and $85 \%$ at concentrations of $0.62 \mathrm{mM}$ and $1 \mathrm{mM}$, respectively ; this inhibitory effect was greater than that observed in southern crabgrass. Caffeic, chlorogenic, 3-O-,4-O-dicaffeoylquinic (3,4diCQA), 3-O-,5-O-dicaffeoylquinic (3,5-diCQA) and 4-O-,5-O-dicaffeoylquinic (4,5-diCQA) acids, together with ethyl caffeate in a filtrate of the by-product, were identified by retention times and on-line ultraviolet spectra in HPLC analysis. A filtrate of moromi before distillation and a filtrate of the by-product contained ethyl caffeate at concentrations of $13.7 \mathrm{mg} / \mathrm{L}$ and $8.3 \mathrm{mg} / \mathrm{L}$, respectively. However, ethyl caffeate was not detected in the extract of the storage roots of Koganesengan, a sweetpotato cultivar from which shochu is prepared.

(Received Nov. 21, 2005 ; Accepted Jan. 29, 2006)

南九州地域で多く製造されるサッマイモ (Ipomoea batatas L.）焼酎は独特の風味があり，近年全国的に消費量が増え ているが，その製造工程ではもろみの蒸留後に産業廃棄物

=885-0091 宮崎県都城市横市町 6651-2

* $=885-8588$ 宮崎県都城市下川東 4-28-1

** \%606-8501 京都府京都市左京区吉田本町

§連絡先 (Corresponding author), sokuno@affrc.go.jp
として多量の焼酎廃液（蒸留粕）が副生する. 従来からそ の多くが海洋投棄, 焼却または農地還元されてきたが, 環 境保全的見地からそれらの処理は制限されつつある。環境 中への廃液の排出を抑えるための方法として飼料化 ${ }^{1)}$, 堆 肥化 ${ }^{2)}$, メ夕ン発酵 ${ }^{2}$ などが取り組まれている。これらの方 法は大量処理の視点からの廃液処理法であると見なすこと ができる，一方，生理活性物質や機能性物質を，活性を指 
標にして廃液から単離・同定した例はなく，このような視 点からの廃液利用の研究は今後取り組む意義があると考え られる. 有用な生理活性物質やそのリード化合物となるよ うな物質が廃液中に存在することが明らかになれば, 廃液 の付加価值が高まり, 焼酎原料であるサッマイモ生産も含 めた地域産業の発展に貢献する可能性がある.

これまで, サッマイモ焼酎廃液についてはブロイラーの 体重増加効果 ${ }^{3)}$ や血漿中の $\alpha$-トコフェロールの増加効果 ${ }^{4)}$ が報告されている。 また最近, 各種焼酎廃液および焼酎廃 液から製造した醸造酢に過酸化脂質ラジカル生成阻害やア ンギオテンシン I 変換酵素阻害などの機能性も見出されて いる5).

サツマイモ塊根には機能性をもつクロロゲン酸やジカ フェオイルキナ酸類などのフェノール性物質が含まれてい $3^{6)}$. 一方, 焼酎廃液は夕ンパク質など基本的成分につい ての報告はある ${ }^{3)}$ が，その他のフェノール性物質など付加 価值が期待される成分についてはほとんど研究されていな い. そこで筆者らは, サッマイモ焼酎廃液の生理活性成分 の探索に着手した。サツマイモ塊根の周皮部分の抽出物が 植物生長を阻害することが報告されている7 ことから, サ ツマイモ焼酎廃液について植物生長阻害活性を検索するこ とに興味をもち、レタスを検定植物として使用した試験を 行った。 その結果, 異なるサッマイモ品種を原料とする焼 酎廃液の抽出物が植物生長阻害活性をもつことが明らかと なった ${ }^{8)}$.さらに筆者らは, 廃液抽出物中の活性成分の研 究過程で, 雑草などの植物の生長に対する阻害物質として カフェ酸エチルを単離, 同定したので今回報告する.

\section{実 験 方 法}

\section{1. サツマイモ焼酎廃液，もろみおよびサツマイモ塊根}

焼酎廃液およびもろみは霧島酒造(株) の工場（宮崎県都 城市) で採取した。焼酎製造工程については, 製麦米 2 日間, 一次仕込み 5 日間，および蒸煮したサッマイモ塊根を投入 してからの二次仕込み 8 日間を経て蒸留を行った. 蒸留直 前のもろみを採取し，ろ紙（アドバンテック，定性ろ紙 No. 101）でろ過してろ液を得た。採取した廃液からも同様 にしてろ液を得た. 各ろ液は分析時までー $30^{\circ} \mathrm{C}$ で凍結保存 した. サッマイモ (Ipomoea batatas L.) 塊根は, 九州沖縄 農業研究センター畑作研究部 (宮崎県都城市) の國場で 2001 年に収穫された品種コガネセンガンを用い, 凍結乾燥 後粉砕した.

\section{2. サツマイモ焼酎廃液の分画および精製}

廃液 (923 g) にエタノール (900 mL) を加えホモジナイ ザー（PT3000, ポリトロン）でホモジナイズ後, 遠心分離 (3000 rpm, 5 分間) して得られた上清をロータリーエバポ レーターで減圧濃縮した。濃縮液（79.6 g) を $n$-ヘキサン $(200 \mathrm{~mL})$ で 2 回抽出し, 残った水相をさらに酢酸エチル $(200 \mathrm{~mL})$ で 2 回抽出した. $n$-ヘキサン相と酢酸エチル相
を減圧濃縮することにより $n$-ヘキサン可溶区（0.8g） と 酢酸エチル可溶区 (3.3 g) を得, また水相を真空凍結乾燥 することにより水可溶区 (19.5 g) を得た.これらのうちレ 夕ス種子発芽阻害活性が最も強かった酢酸エチル可溶区 (3.2 g) を, シリカゲル（Wako C-100 ゲル，64 g) および メタノール/クロロホルム/酢酸によるカラムクロマトグラ フィーにより分画した. 溶出はメタノール/クロロホルム/ 酢酸を $0: 100: 0$ (Fr-1)， $5: 95: 0.5$ (Fr-2), $10: 90: 0.5$ (Fr-3)，20:80:0.5（Fr-4）および $100: 0: 0.5 （ F r-5 ） と$ し, 各溶出液と屯順次 $170 \mathrm{~mL}$ ずつ溶出させ，得られた 5 画分を減圧濃縮した。これらのうち Fr-2 (162 mg) の発芽 阻害活性が最む強かった ${ }^{8)}$ ので，本画分の一部をさらに高 速液体クロマトグラフィー（HPLC）で分画した. HPLC 装置として，ポンプ; LC-10AT, オートインジェクター; SIL-10AXL, カラムオーブン; CTO-10AC, ダイオードア レイ検出器; SPD-M10AVP（島津製作所）を用いた. HPLC 条件は, カラム; YMC-Pack ODS-AM AM-323 $(250 \times 10$ mm I.D., ワイエムシィ), 移動相; A) 40\% (v/v) メ夕ノールおよび B ) メタノール, グラジェントパターン; 0\% B (0〜 $5 \mathrm{~min}$, イソクラティック)， $0 \rightarrow 100 \% \mathrm{~B} \quad(5 \sim 10$

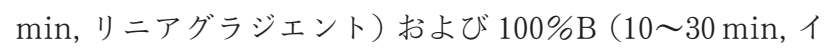
ソクラティック), 流速 ; $4 \mathrm{~mL} / \mathrm{min}$, カラム温度 ; $40^{\circ} \mathrm{C}$, 検 出波長 ; $326 \mathrm{~nm}$ を用いた. 保持時間 $\left(t_{\mathrm{R}}\right)=0 \sim 10$ (Fr-A), 10〜18.5 (Fr-B) および 18.5〜30 min (Fr-C) の 3 つの画分 を分取し，それぞれ減圧濃縮した。これらのうち，Fr-Bの メインピークに相当する物質を HPLC で精製した. HPLC 条件として，カラム; YMC-Pack ODS-AM AM-323（250 $\times 10 \mathrm{~mm}$ I.D.), 移動相; $0.1 \%(\mathrm{v} / \mathrm{v})$ ギ酸含有 $50 \%(\mathrm{v} / \mathrm{v})$ メ夕ノール, 流速; $4 \mathrm{~mL} / \mathrm{min}$, カラム温度; $40^{\circ} \mathrm{C}$, 検出波 長; $326 \mathrm{~nm}$ を用いた。 $t_{\mathrm{R}}=10.9 \mathrm{~min}$ のピークを分取, 減圧 濃縮し，化合物 1 を得た。

\section{3. 種子発芽および幼根伸長に対する阻害試験}

シャーレ（内径 $60 \mathrm{~mm}$ ) 上にろ紙（アドバンテック，定 性ろ紙 No. 2, $55 \mathrm{~mm}$ ) 2 枚敷き, 各試料のメ夕ノール溶 液を添加後, メ夕ノールを減圧下で留去した。 イオン交換 水 $3 \mathrm{~mL}$ を加え，レタス (Lactuca sativa L. cv. Grand Rapids), ホソアオゲイトウ (Amaranthus hybridus L.) またはメヒシバ (Digitaria adscendens (H. B. K.) Henr.) の種子 20 粒を播いた後, 人工気象器内でレタス種子の場 合は $25^{\circ} \mathrm{C}$ で連続光下, また他の種子の場合は $35^{\circ} \mathrm{C}$ で暗黒 下インキュベートした。試料を添加しないものを対照区と した.レタスとホソアオゲイトウについては 48 時間, また メヒシバについては 60 時間インキュベート後に発芽種子 の数を計るとともに, 幼根の長さを測定した. 発芽阻害率 ならびに幼根伸長阻害率は以下のように算出した。

発芽阻害率 $(\%)=($ 対照区の発芽種子数 一試料区の発芽種子数)/対照区の種子数 $\times 100$ 
幼根伸長阻害率 $(\%)=($ 対照区の幼根長 $(\mathrm{mm})$ 一試料区の幼根長 $(\mathrm{mm})) /$ 対照区の幼根長 $(\mathrm{mm}) \times 100$

試料区および対照区ともに 3 連で試験を行った。両区の間 の有意差検定には, Student's $t$ 検定（両側検定）を用いた.

\section{4. 化合物 1 の構造解析}

${ }^{1} \mathrm{H}-\mathrm{NMR}$ スペクトルは Bruker ARX500（500 MHz）を 用いて測定した。内部標準としてテトラメチルシランを使 用した. EIMS スペクトルは JEOL JMS600を使用して直 接導入法により測定した.

\section{5. カフェ酸エチルの合成}

合成は青山ら ${ }^{9)}$ の方法に従った. すなわち, カフェ酸（1 g) に対して $10 \%(\mathrm{v} / \mathrm{v})$ 硫酸含有エタノール (10 mL) お よび硫酸ナトリウム（無水物，10 g）を加え，30 分間還流 後乃過した. ろ液を酢酸エチルで抽出, 水洗後, 硫酸ナト リウム (無水物) で乾燥し, 減圧濃縮した。この生成物を メタノール溶液とし, C18 カートリッジ（Sep-Pak Vac C $18,10 \mathrm{~g}$, Waters）にアプライし $0.2 \%$ (v/v) ギ酸およびメ 夕ノールの混合溶媒を用いて溶出することにより目的物質 を精製した。溶出は $0.2 \%$ ギ酸/メタノールを $100: 0$ (25 $\mathrm{mL}, 2$ 回, Fr-A, -B), $85: 15$ (25 mL, 2 回, Fr-C, -D), 60 : 40 (25 mL, 2 回, Fr-E, -F) および 0:100（25 mL, 2 回, Fr-G, -H）として行い, Fr-F, -G および-H を合一して減圧 濃縮し，カフェ酸エチル（568 mg）を得た。なお，本化合 物を次に述べる条件で HPLC 分析したところ, 焼酎廃液 から上述のように単離した化合物 1 と保持時間および紫外 スペクトルが一致することを確認した。

\section{6. 焼酎廃液ろ液, もろみろ液およびサツマイモ塊根抽 出物の HPLC 分析}

廃液ろ液およびもろみろ液はメンブレンフィル夕ー (DISMIC-13HP, 孔径; $0.2 \mu \mathrm{m}$, アドバンテック) にてろ過 後 HPLCでカフェ酸エチルを分析した。 サッマイモ（品種 コガネセンガン) 塊根については, 凍結乾燥試料 (1g) に 80\%（v/v）メタノール（6 mL）を加え沸騰水浴中で加熱 後, 抽出液を減圧濃縮した。 この抽出物のメタノール溶液 (1 mL) をメンブレンフィルターでろ過し HPLC で分析し た. HPLC 条件として, 筆者ら ${ }^{10)}$ が行ったサッマイモ葉部 のカフェ酸誘導体定量と同条件, すなおち, カラム; YMCPack ODS-AM AM-302 (150×4.6 mm I.D.), 移動相 ; A) $0.2 \%(\mathrm{v} / \mathrm{v})$ ギ酸および B $)$ メノール, グラジェントパ ターン; $2 \% \mathrm{~B}$ (0〜15 min, イソクラティック), $2 \rightarrow 45 \% \mathrm{~B}$ (15〜50 min, リニアグラジェント) および 45\% B（50〜60 $\min$, イソクラティック), 流速 ; $1 \mathrm{~mL} / \mathrm{min}$, カラム温度 ; $40^{\circ} \mathrm{C}$, 検出波長; $326 \mathrm{~nm}$ を用いた. 3-O-, 4-O-ジカフェ オイルキナ酸 (3, 4-diCQA), 3-O-, 5-O-ジカフェオイル キナ酸 (3, 5-diCQA) および 4-O-, 5-O-ジカフェオイル キナ酸（4，5-diCQA）の標準物質として，筆者ら ${ }^{10)}$ がサッ マイモ葉部から単離したものを使用した。

\section{7. 試薬および種子}

カフェ酸は和光純薬工業より, クロロゲン酸は Sigma 社より購入した。 その他の試薬類は和光純薬工業製の特級 試薬または高速液体クロマトグラフ用溶媒を使用した。レ タス種子は丸種より購入した，雑草種子は財団法人日本植 物調節剂研究協会より分与された。

\section{実験結果および考察}

\section{1. サツマイモ焼酎廃液の分画ならびにカフェ酸エチル の単離}

レタスは感受性が高く発芽率も良好であることから，天 然からの各種抽出物や化合物の植物生長調節活性やアレロ パシー活性を検討するための検定植物として従来から最も 広く使用されており, 本研究であ検定植物として用いた。

サツマイモ焼酎廃液を溶媒分画して酢酸エチル可溶区を 得, さらにシリカゲルカラムクロマトグラフィーにより 5 つの画分を得た。これらのうちレタス種子発芽阻害活性の 最あ強かった画分である Fr-2 をさらに HPLC で 3 つ画 分, Fr-A, -B および-C に分画した. 活性を測定した結果, Fr-A, -B および-C の幼根伸長阻害活性は, 濃度 $0.1 \mathrm{mg} /$ $\mathrm{mL}$ ではそれぞれー1，36，および $0 \%$ ，また濃度 $0.3 \mathrm{mg} /$ $\mathrm{mL}$ ではそれぞれ 22，65，および $0 \%$ であり（Data not shown), Fr-B の生長阻害活性が最も強かった。なお，い ずれの画分も有意な種子発芽阻害活性を示さなかった. HPLCで得られた 3 つ画分に種子発芽活性が見られな かった原因は不明である。作用面では，ある成分が単独で 存在すると幼根伸長のみ阻害するが，異なる成分が共存す ると発芽を阻害する可能性が考えられる，また，分画操作 の面からは，発芽阻害活性に関与する物質がカラムに吸着 されて溶出されない可能性や, 濃縮時に活性物質が分解や 異性化する可能性む考えられるが，詳細は不明である，通 常, 生長阻害物質は同じ濃度条件では発芽阻害より屯幼根 伸長阻害を示しやすいこと，あるいは高濃度でも発芽阻害 を示さないことが多く ${ }^{11)}$, 発芽阻害を示す物質は非常に強 力な生長阻害物質の範疇に入る。また，同じ物質であって 屯植物種が变わると幼根伸長阻害が同様に認められる一方 で発芽阻害が弱くなることがある ${ }^{11)}$.

得られた上記 3 画分のうち, Fr-B の幼根伸長阻害活性 が上述のように最も強かったので，この画分に含まれる主 成分である化合物 1 を HPLCで単離し $1 \mathrm{mg}$ を得た。化合 物 1 のスペクトルデータは以下の通りであった : ${ }^{1} \mathrm{H}-\mathrm{NMR}$ (重メタノール) $\delta 1.31\left(3 \mathrm{H}, \mathrm{t}, J=7.2 \mathrm{~Hz}, \mathrm{CH}_{3}\right), 4.21(2 \mathrm{H}$, q, $\left.J=7.2 \mathrm{~Hz}, \mathrm{CH}_{2}\right), 6.23(1 \mathrm{H}, \mathrm{d}, J=15.9 \mathrm{~Hz}, 8-\mathrm{H}), 6.76$ (1 $\mathrm{H}, \mathrm{d}, J=8.2 \mathrm{~Hz}, 5-\mathrm{H}), 6.93(1 \mathrm{H}, \mathrm{dd}, J=1.9$ and $8.2 \mathrm{~Hz}, 6-$ H), $7.02(1 \mathrm{H}, \mathrm{d}, J=1.9 \mathrm{~Hz}, 2-\mathrm{H}), 7.53(1 \mathrm{H}, \mathrm{d}, J=15.9 \mathrm{~Hz}$, 7-H) ; EIMS (70 eV) m/z (相対強度, \%) $208[\mathrm{M}]^{+}$(93), 180 (19), 163 (100), 145 (12), 136 (19), 117 (12), 89 (17). ${ }^{1} \mathrm{H}-\mathrm{NMR}$ スペクトルではエステル結合したエチル 
<smiles>[R20]OC(=O)/C=C/c1ccc(O)c(O)c1</smiles>

Ethyl caffeate (1): $\mathrm{R}_{1}=\mathrm{C}_{2} \mathrm{H}_{5}$

Caffeic $\operatorname{acid}(2): \mathrm{R}_{1}=\mathrm{H}$

Chlorogenic $\operatorname{acid}(3): \mathrm{R}_{2}=\mathrm{R}_{3}=\mathrm{H}, \mathrm{R}_{4}=$ caffeoyl 3-O-, 4-O-Dicaffeoylquinic acid (3,4-diCQA, 4): $\mathrm{R}_{2}=\mathrm{R}_{3}=$ caffeoyl, $\mathrm{R}_{4}=\mathrm{H}$

3-O-, 5-O-Dicaffeoylquinic acid (3,5-diCQA, 5): $\mathrm{R}_{2}=\mathrm{R}_{4}=$ caffeoyl, $\mathrm{R}_{3}=\mathrm{H}$

4-O-, 5-O-Dicaffeoylquinic acid (4,5-diCQA, 6): $\mathrm{R}_{2}=\mathrm{H}, \mathrm{R}_{3}=\mathrm{R}_{4}=$ caffeoyl

Fig. 1 Structures of the caffeic acid derivatives found in the sweetpotato shochu distillery by-product

Table 1 Inhibitory effect of ethyl caffeate on seed germination and radicle elongation of lettuce and weeds

\begin{tabular}{|c|c|c|c|c|c|c|c|}
\hline \multirow{3}{*}{$\begin{array}{c}\text { Plant } \\
\text { species }\end{array}$} & \multicolumn{7}{|c|}{ Inhibitory effect on seed germination (\%) } \\
\hline & \multicolumn{7}{|c|}{ Concentration $(\mathrm{mM})$} \\
\hline & 0.1 & 0.32 & 0.48 & 0.62 & 1 & 1.44 & 4.81 \\
\hline Lettuce & $-5 \pm 6$ & $-5 \pm 3$ & $-4 \pm 9$ & $-5 \pm 6$ & $-2 \pm 3$ & $-5 \pm 3$ & $-2 \pm 3$ \\
\hline $\begin{array}{l}\text { Smooth } \\
\text { pigweed }\end{array}$ & $0 \pm 6$ & NT & NT & $29 \pm 24^{* * *}$ & $48 \pm 7^{* * *}$ & NT & NT \\
\hline \multirow[t]{2}{*}{$\begin{array}{l}\text { Southern } \\
\text { crabgrass }\end{array}$} & $11 \pm 13$ & NT & NT & $9 \pm 18$ & $20 \pm 22$ & NT & NT \\
\hline & \multicolumn{7}{|c|}{ Inhibitory effect on radicle elongation (\%) } \\
\hline Plant & \multicolumn{7}{|c|}{ Concentration $(\mathrm{mM})$} \\
\hline species & 0.1 & 0.32 & 0.48 & 0.62 & 1 & 1.44 & 4.81 \\
\hline Lettuce & $7 \pm 17$ & $6 \pm 24$ & $9 \pm 14$ & $29 \pm 20^{* * *}$ & $53 \pm 12^{* * *}$ & $81 \pm 6^{* * *}$ & $87 \pm 3^{* * *}$ \\
\hline $\begin{array}{l}\text { Smooth } \\
\text { pigweed }\end{array}$ & $1 \pm 42$ & NT & NT & $79 \pm 8^{* * *}$ & $85 \pm 8^{* * *}$ & $\mathrm{NT}$ & NT \\
\hline $\begin{array}{l}\text { Southern } \\
\text { crabgrass }\end{array}$ & $2 \pm 87$ & NT & NT & $-1 \pm 63$ & $42 \pm 45^{* *}$ & NT & NT \\
\hline
\end{tabular}

Data are presented as means $\pm \mathrm{SD}$.

NT : Not tested.

** and ${ }^{* * *}$ designate significant differences from the control at $p<0.01$ and $p<0.001$, respectively, by Student's $t$-test.

基，トランス型二重結合，および $1 ， 3 ４$-置換ベンゼン環 に帰属できるプロトンの存在が示され，EIMS では分子イ オンピークとして $m / z 208$ が検出されたことから，化合物 1 をカフェ酸エチル (Fig. 1) と同定した.

カフェ酸エチルは天然からの単離例が少なく, アルゼン チンのシソ科植物からベンゾジアゼピン受容体に対するリ ガンドとして ${ }^{12)}$, また, ブラジルのマメ科植物から単離さ れている13).

\section{2. レタスと雑草の生長に対するカフェ酸エチルの阻害} 活性

植物生長に対するカフェ酸エチルの活性はこれまで報告 されていないことから，検定植物であるレタスを用い力 フェ酸エチルの生長阻害活性を検討した。なお，今回は焼 酎廃液から単離した量が少なかったためにカフェ酸エチル を合成し，阻害試験に使用した。 その結果，カフェ酸エチ ルによる種子発芽活性は認められなかったが，幼根伸長は
$0.62 \mathrm{mM}$ 以上で有意に阻害された（Table 1).

カフェ酸エチルの植物生長阻害活性は今回の報告が初め てである。なお，サッマイモ焼酎廃液が植物に対して示す 作用については, 柯ら ${ }^{14)} に よ り$ 廃液施用直後の土壌に播種 したコマツナの根および茎の生長が阻害されること，また 廃液中の成分であるエタノールとイソ酪酸によってもコマ ッナの生長が阻害されることが報告されている.

カフェ酸エチルは構造的にはカフェ酸のエチルエステル であることから，レタス幼根伸長に対する両物質の阻害活 性を比較した結果, $1 \mathrm{mM}$ では カフェ酸エチルは $53 \%$ 阻 害し，カフェ酸による阻害 $(30 \%)$ より有意に強かった (Data not shown).このことから, カフェ酸がエチルエス テル化されるとレタス幼根伸長阻害活性が増大することが わかった。

レタス以外の植物に対するカフェ酸エチルの生長阻害活 性を検討するため, 雑草を用いた試験を行った. 雑草は化 
学物質に対する感受性の違いにより, イネ科雑草と広葉雑 草に区分することが可能である. 畑地で多く発生し害を及 ぼす雑草のうち, イネ科雑草の代表的なあのとしてメヒシ バがあげられる。 また, 南九州地域に広く分布する飼料畑 での発生が特に多いヒユ科植物は広葉雑草に属する。そこ で，メヒシバおよび同じく一年生雑草であるヒユ科のホソ アオゲイトウを試験に用いた。 その結果 Table 1 に示した ように, 種子発芽においてカフェ酸エチルはホソアオゲイ トウを $0.62 \mathrm{mM}$ で 29\%，また $1 \mathrm{mM}$ で $48 \%$ 阻害したが, メヒシバに対しては有意に阻害しなかった。 また，幼根伸 長においてカフェ酸エチルはホソアオゲイトウを $0.62 \mathrm{mM}$ で $79 \%$ ，また $1 \mathrm{mM}$ で $85 \%$ 阻害し，この阻害程度はメヒ シバに対するよりも強かった。 今回の結果から, カフェ酸 エチルは雑草の生長を阻害する活性をむつこと, また植物 種の違いにより生長阻害活性が異なることが初めて明らか になった。除草剤などの化学物質にはイネ科雑草と広葉雑 草に対する活性が異なるものがあり, これは当該物質の植 物体内における代謝速度の違いなどに起因すること広く知 られている。植物種の違いによるカフェ酸エチルの活性の 差異の原因解明には, その代謝や植物体内への吸収を検討 することが必要である。

カフェ酸エチルの植物生長阻害活性以外の生理活性につ いては, Chalas ら ${ }^{15)}$ が DPPH (1, 1-diphenyl-2-picrylhydrazyl) ラジカル消去活性はカフェ酸と同等であるが, ヒト由来 LDL (低密度リポタンパク質) の酸化を抑制する 活性はカフェ酸より強いこと, また Nakayama ら ${ }^{16)}$ が過 酸化水素によって引き起こされる細胞毒性に対する阻害活 性むカフェ酸より強いことを報告している. すなわち, 力 フェ酸エチルは植物生長阻害活性だけではなく抗酸化活性 あむち, 焼酎廃液ならびに焼酎廃液から製造した醇造酢に ついて既に報告されている過酸化脂質ラジカル生成阻害や アンギオテンシン I 変換酵素阻害などの機能性に本物質が 関与するかどうかに興味があたれる。

\section{3. 焼酎廃液乃液, もろみろ液およびサッマイモ塊根抽 出物中のカフェ酸エチルの定量}

カフェ酸エチルの生成段階について知見を得るために, 焼酎廃液のろ液, 蒸留前の屯ろみのろ液および焼酎原料で あるサッマイモ (品種コガネセンガン) の塊根凍結乾燥試料 を HPLC 分析した. カフェ酸およびクロロゲン酸を分析し た場合の吸収極大波長 $326 \mathrm{~nm}$ でろ液を分析した結果, Fig. 2 に示したように化合物 $2\left(t_{\mathrm{R}}=31.2 \mathrm{~min}\right), 3\left(t_{\mathrm{R}}=32.8\right.$ $\min ), 4\left(t_{\mathrm{R}}=46.1 \mathrm{~min}\right), 5\left(t_{\mathrm{R}}=46.7 \mathrm{~min}\right), 6\left(t_{\mathrm{R}}=49.9 \mathrm{~min}\right)$ および $1\left(t_{\mathrm{R}}=51.9 \mathrm{~min}\right)$ が検出された. 各化合物の $t_{\mathrm{R}} お よ$ び紫外スペクトルを標準物質と比較することにより, 化合 物 $2 ， 3 ， 4 ， 5 ， 6$ および 1 をそれぞれ, カフェ酸, クロロゲ ン酸, 3-O-, 4-O-ジカフェオイルキナ酸 (3, 4-diCQA), 3$\mathrm{O}^{-}$, 5-O-ジカフェオイルキナ酸 $(3,5$-diCQA $), 4-\mathrm{O}^{-}, 5^{-}$ O-ジカフェオイルキナ酸 (4, 5-diCQA)（Fig. 1) およびカ

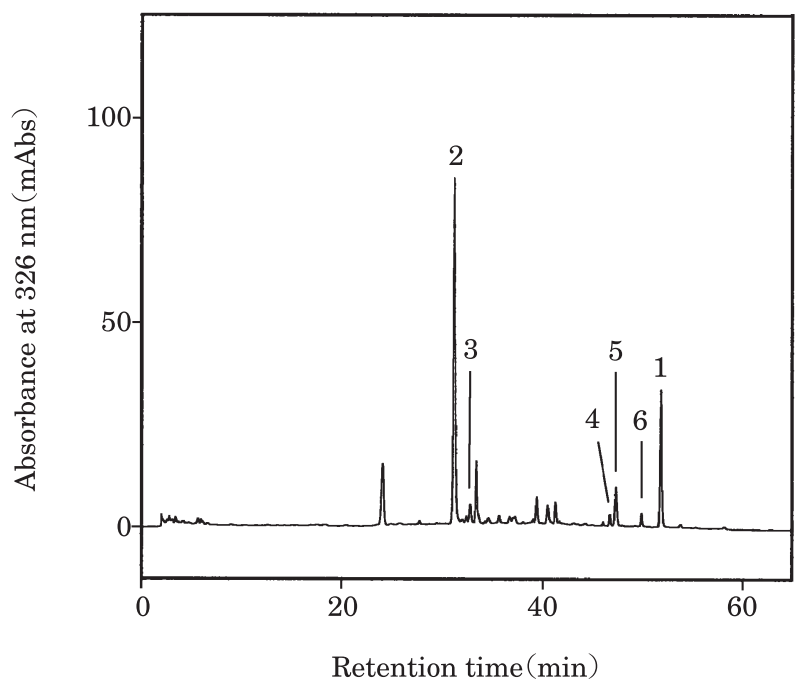

Fig. 2 A high-performance liquid chromatogram of filtrate from the sweetpotato shochu distillery by-product

The numbers in the chromatogram refer to the compounds in Fig. 1.

フェ酸エチルと同定した. 焼酎廃液ろ液, 蒸留前のもろみ ろ液およびサッマイモ塊根抽出物におけるこれらのカフェ 酸誘導体の定量結果を Table 2 に示した. カフェ酸エチル は, 廃液ろ液ともろみろ液の両方に含まれており（それ ぞれ $8.3 \mathrm{mg} / \mathrm{L}$ および $13.7 \mathrm{mg} / \mathrm{L})$, サッマイモ塊根には検 出されなかった。このことは, 本物質が蒸留によりはじめ て生成するのではなく, 二次仕込み終了時に既に存在する ことを示すあのである. 二次仕込み終了以前のどの段階で 本物質が生成するのかは不明であるが，発酵の各段階での 分析をさらに行うことにより知見が得られるであろう。サ ッマイモ焼酎廃液は年間 $250000 \mathrm{~kL}$ 以上副生しており ${ }^{17)}$, $90 \%$ 以上が水分であることから $1800 \mathrm{~kg}$ 以上のカフェ酸エ チルが焼酎製造工程で年間に生成していると見積もられる.

発酵製品に関しては, Archier ら ${ }^{18)}$ がワインをガラス製 容器で貯蔵すると当初は検出されなかったカフェ酸エチル などのフェノール性物質が生成することを報告している.

Archier らはワイン中のタンニンのような高分子物質が分 解されフェノール性物質が生成するのかもしれないと述べ ているが，詳細な生成機構は不明である。すなわち，力 フェ酸エチルの生成はサッマイモ焼酎製造に特有の現象で はない.

また, 上記 6 種のカフェ酸誘導体のうち, カフェ酸19), クロロゲン酸20) および $3,5-\operatorname{diCQA}^{20)}$ については植物生長 阻害活性が報告されている.

今回の研究では, 焼酎廃液から単離したカフェ酸エチル が雑草を含む植物に対して生長阻害活性をむつことを初め て明らかにし，また植物種の違いにより異なる生長阻害活 性を発現することを明らかにした。このことは，ある特定 
Table 2 Contents of caffeic acid derivatives in sweetpotato shochu distillery by-product and related materials

\begin{tabular}{lcccccc}
\hline \hline \multicolumn{1}{c}{ Material } & $\begin{array}{c}\text { Caffeic } \\
\text { acid }\end{array}$ & $\begin{array}{c}\text { Chlorogenic } \\
\text { acid }\end{array}$ & 3,4-diCQA & 3,5-diCQA & 4,5-diCQA & $\begin{array}{c}\text { Ethyl }^{\text {cthe }} \\
\text { caffeate }\end{array}$ \\
\hline By-product $^{\mathrm{d}}(\mathrm{mg} / \mathrm{L})$ & 23.6 & 1.7 & 0.4 & 1.0 & 1.1 & 8.3 \\
Moromi $^{\mathrm{e}}(\mathrm{mg} / \mathrm{L})$ & 66.6 & 0.03 & $\mathrm{ND}$ & 0.1 & 4.6 & 13.7 \\
Sweetpotato $^{\mathrm{f}}(\mathrm{mg} / \mathrm{kg}$, D.W.) & 3.4 & 136.1 & 10.7 & 98.1 & 4.7 & ND \\
\hline
\end{tabular}

ND : Not detected.

a 3-O-,4-O-Dicaffeoylquinic acid.

${ }^{\mathrm{b}} 3-\mathrm{O}-\mathrm{-5}-\mathrm{O}$-Dicaffeoylquinic acid .

${ }^{c} 4-O-, 5-O$-Dicaffeoylquinic acid.

${ }^{\mathrm{d}}$ Filtrate of the by-product.

${ }^{\mathrm{e}}$ Filtrate of moromi before distillation.

${ }^{\mathrm{f}}$ Extract of Koganesengan storage roots, a sweetpotato cultivar from which shochu is prepared.

植物の生長を抑制する場合に本物質あるいは焼酎廃液を適 用するという利用法に向けての研究のきっかけを提供する あのである，さらに，本研究で述べた 6 種のカフェ酸誘導 体のうち，カフェ酸エチル以外については多くの機能性が 報告されている ${ }^{21)}$ 24) が，カフェ酸エチルの生理活性に関 する知見は非常に少ない。したがって，カフェ酸エチルの 活性を広く検討することにより特徵的あるいは強力な活性 が見出されれば，本物質を含む有用素材として焼酎廃液の 付加価值が高まると考えられる．カフェ酸エチルが焼酎製 造工程で生成すること，また既に述べたように本物質の各 種活性がカフェ酸より強いことから，焼酎廃液のような廃 棄物や副産物を対象として原料中の物質よりあ高活性な物 質を探索する研究は今後意義があると考えられる.

焼酎廃液にはなお未同定の物質が存在しており, 廃液の 新規用途開拓に向けて筆者らはこれらの構造や特性につい てさらに検討を進めている。廃液中の各物質単独の活性だ けではなく，相乗作用についての検討も今後重要である.

\section{要約}

サッマイモ焼酎廃液から植物生長阻害物質としてカフェ 酸エチルを単離同定した。本化合物の植物生長阻害活性を シャーレ試験によって調べた. 本化合物は $0.62 \mathrm{mM}$ 以上で レタス幼根伸長を有意に阻害し, また, 阻害活性はカフェ 酸より強かった。本化合物は雑草種子を用いた試験では, メヒシバの発芽を阻害しなかったが，ホソアオゲイトウの 発芽を $0.62 \mathrm{mM}$ で $29 \%, 1 \mathrm{mM}$ で $48 \%$ それぞれ阻害した。 また，ホソアオゲイトウの幼根伸長を $0.62 \mathrm{mM}$ で $79 \%, 1$ $\mathrm{mM}$ で $85 \%$ それぞれ阻害し，これはメヒシバに対する阻 害効果より屯強かった。廃液ろ液の分析の結果, 同化合物 を含めて 6 種類のカフェ酸誘導体を同定した。カフェ酸エ チルは焼酎原料のサッマイモ品種コガネセンガンの塊根に は検出されなかったが，蒸留前のむろみ中には $13.7 \mathrm{mg} / \mathrm{L}$ ， また廃液ろ液には $8.3 \mathrm{mg} / \mathrm{L}$ 含有されていた。
本研究を実施するに当たり, サッマイモ塊根凍結乾燥試 料を提供していただきました九州沖縄農業研究センター畑 作研究部外山潤氏に感謝の意を表します.

また本研究の一部は農林水産省のバイオリサイクル研究 プロジェクトにより得られた研究成果であり，ご支援をい ただいた関係皆様に厚く御礼申し上げます。

\section{文献}

1）山下 寛，焼酎粕の飼料化（1)，「未利用有機物資源の飼料 利用ハンドブック」, 第 1 版, 阿部 亮, 吉田宣夫, 今井明 夫，山本英雄編（サイエンスフォーラム，東京），pp. 109113 (2000).

2）藤原俊六郎, 焼酎かす,「有機廃棄物資源化大事, 典」, 有機質 資源化推進会議編（農山漁村文化協会，東京），pp. 193-198 (1997).

3）ルトウフィ D. マーフズ, 林 國興, 池田 睦, 浜田幸一郎, 大塚 彰, 富田裕一郎, ブロイラー飼料としての焼酎粕の 有効利用, 日本家禽学会誌，33，1-7 (1996).

4）大塚 彰, 尾辻由貴, 林 國興, 焼酎粕はブロイラーの血漿 $\alpha$-トコフェロール濃度を上昇させる，日本家禽学会誌， 35, 132-137 (1998).

5) Ye, X.J., Morimura, S., Han, L.S., Shigematsu, T. and Kida, K., In vitro evaluation of physiological activity of vinegar produced from barley-, sweet potato-, and riceshochu post-distillation slurry, Biosci. Biotechnol. Biochem., 68, 551-556 (2004).

6）下園英俊, 小堀真珠子, 新本洋士, 津志田藤二郎, サッマイ モ抽出物によるマウスメラノーマ細胞のメラニン生成抑 制，食科工，43，313-317（1996）.

7) Peterson, J.K. and Harrison, H.F., Jr., Isolation of substance from sweet potato (Ipomoea batatas) periderm tissue that inhibits seed germination, J. Chem. Ecol., 17, 943-951 (1991).

8）奥野成倫, 吉元 誠, レタス種子発芽に及ぼすカンショ焼 酎廃液抽出物の影響, 九州農業研究, 64, 43（2002）。

9）青山 稔, 兼松 弘, 新谷 勛, 塚本正人, 東海林茂, 松本 太郎，トコフェロールの酸化防止効果向上に関する研究 (第 22 報), 油化学，40，202-205（1991）。

10) Islam, M.S., Yoshimoto, M., Yahara, S., Okuno, S., Ishiguro, K. and Yamakawa, O., Identification and characterization of foliar polyphenolic composition in sweetpotato (Ipomoea batatas L.) genotypes, J. Agric. 
Food Chem., 50, 3718-3722 (2002).

11）鬼頭 誠, 奥野聡子, コーヒー粕の分解に伴うフェノール 性物質の他感作用, 杂隹草研究, 44，349-352，(1999）.

12) Marder, M., Viola, H., Wasowski, C., Wolfman, C., Waterman, P.G., Medina, J.H. and Paladini, A.C., Cirsiliol and caffeic acid ethyl ester, isolated from Salvia guaranitica, are competitive ligands for the central benzodiazepine receptors, Phytomed., 3, 29-31 (1996).

13) Silva, V.N.T., de Oliveira, F.M. and Conserva, L.M., Phenolic derivatives and terpenes from Acosmium bijugum, Biochem. Syst. Ecol., 29, 1189-1192 (2001).

14）柯 貴城, 平井光代, 正田 誠, 久保田宏, サッマイモ焼酎 蒸留廃液の農地還元利用, 日本土壌肥料学雑誌, 59, 156163 (1988).

15) Chalas, J., Claise, C., Edeas, M., Messaoudi, C., Vergnes, L., Abella, A. and Lindenbaum, A., Effect of ethyl esterification of phenolic acids on low-density lipoprotein oxidation, Biomed. Pharmacother., 55, 54-60 (2001).

16) Nakayama, T., Yamada, M., Osawa, T. and Kawakishi, S., Inhibitory effects of caffeic acid ethyl ester on $\mathrm{H}_{2} \mathrm{O}_{2}$-induced cytotoxicity and DNA single-strand breaks in Chinese hamster V79 cells, Biosci. Biotechnol. Biochem., 60, 316-318 (1996).

17）熊本国税局,「平成 15 酒造年度しょうちゅう調査書」, p. 42 (2004).

18) Archier, P., Coen, S. and Roggero, J. P., Changes in the phenolic content of single-variety wines after the first nine months of storage, Sci. Aliments, 13, 483-490 (1993).

19) Alsaadawi, I.S., Al-Hadithy, S.M. and Arif, M.B., Effects of three phenolic acids on chlorophyll content and ions uptake in cowpea seedlings, J. Chem. Ecol., 12, 221-227 (1986).

20) Beninger, C.W., Abou-Zaid, M.M., Kistner, A.L.E., Hallett, R.H., Iqbal, M.J., Grodzinski, B. and Hall, J.C., A flavanone and two phenolic acids from Chrysanthemum morifolium with phytotoxic and insect growth regulating activity, J. Chem. Ecol., 30, 589-606 (2004).

21) Mahmood, N., Moore, P.S., De Tommasi, N., De Simone, F., Colman, S., Hay, A.J. and Pizza, C., Inhibition of HIV infection by caffeoylquinic acid derivatives, Antiviral Chem. Chemother., 4, 235-240 (1993).

22) Chuda, Y., Ono, H., Ohnishi-Kameyama, M., Nagata, T. and Tsushida, T., Structural identification of two antioxidant quinic acid derivatives from garland (Chrysanthemum coronarium L.) , J. Agric. Food Chem., 44, 20372039 (1996).

23) Tanaka, T., Kojima, T., Kawamori, T., Wang, A., Suzui, M., Okamoto, K. and Mori, H., Inhibition of 4nitroquinoline-1-oxide-induced rat tongue carcinogenesis by the naturally occurring plant phenolics caffeic, ellagic,chlorogenic and ferulic acids, Carcinogenesis, 14, 1321-1325 (1993).

24) Yoshimoto, M., Yahara, S., Okuno, S., Islam, M. S., Ishiguro, K. and Yamakawa, O., Antimutagenicity of mono-, di-, and tricaffeoylquinic acid derivatives isolated from sweetpotato (Ipomoea batatas L.) leaf, Biosci. Biotechnol. Biochem., 66, 2336-2341 (2002).

(平成 17 年 11 月 21 日受付, 平成 18 年 1 月 29 日受理) 